\title{
Incidence and Severity of Poverty among Oyan Lake Host Communities' Households in Ogun State, Nigeria
}

\author{
Moyib Folake R. \\ University of Ibadan, Nigeria \\ moyibfola@gmail.com \\ Ojo S. Olugbenga \\ University of Ibadan, Nigeria \\ and \\ Ayodele Ibukun A. \\ University of Ibadan, Nigeria \\ DOI//http://dx.doi.org/10.4314/gjds.v14i2.9
}

\begin{abstract}
Appropriate utilisation of resources, especially natural resource could enhance or aid economic development. This study investigated the incidence and severity of poverty among host communities' households of Oyan Lake, Nigeria displaced and resettled beside the Lake. Three host communities comprising twenty-three villages were purposively selected. Sample-size of 367 households were randomly selected proportionate to the size of each location. Structured questionnaire and interview method were used. Variables assessed were their socio-economic characteristics, livelihood activities and food and non-food consumption expenditures. Foster Greer-Thorbecke (FGT) index was used to measure the incidence, depth and severity of poverty. Multivariate Probit model was used to determine the relationships between socioeconomic characteristics of the respondents and their poverty status. FGT results indicated the headcount index as $81.7 \%$, with a poverty line of $N 7,462.5: 00$ (\$37.50) while it would take about $45 \%$ of the poverty line to bring an average household out of poverty. Marital status ( $\rho<0.1)$, education level $(\rho<0.1)$, Household size $(\rho<0.001)$, capital base $(\rho<0.01)$, type of household $(\rho<0.1)$ and housing unit $(\rho<0.1)$ significantly influenced the level of poverty among these households. It is recommended that development oriented policies aimed at discouraging early marriages, polygamy, having improved family planning, housing scheme, education and access to loans should be given consideration for these communities.
\end{abstract}

Keywords: Host communities, Poverty, Household, Multivariate Probit Model, Livelihood activities 


\section{Introduction}

Nigeria is endowed with human, natural and material resources that could be harnessed to aid economic development. Of these, is Oyan Lake (OL), located in Ogun State - a man-made water reservoir that led to the displacement of twenty-three villages with their farm holdings and other landed properties lost to the project; though it gives them the opportunity of having access to some water-related livelihood activities for income generation. One could say it is a blessing to the displaced communities because they were settled near the Lake by the Federal government of Nigeria and have free access to its utilisation at a token, especially the fisher-folks. Appropriate utilisation of water resources, was seen as key for rural communities around such resources and could contribute to achieving the sustainable development goal (SDG) of reducing poverty by 2030. Inadequate knowledge about resource utilisation for wealth creation has made many to continue to live in poverty with zero contribution to the economic development of their country. Therefore the challenges that most countries of the world face today is poverty reduction. Natural resources contribute to livelihoods; they play significant roles in the life of the poor through job creation, meeting dietary and shelter needs for the rural populace. Browkay (2006) says a large proportion of people in the rural areas rely on water and forest resources in their areas, with more than 1.3 billion people worldwide depending on fisheries, forests, and agriculture. They serve as sources of cash income and employment, help farm families in resolving economic crisis, while they could readily be converted to cash. But their mismanagement due to biodiversity loss and environmental degradation may contribute to poverty (Browkay, 2006).

In April 2013, the World Bank set a new target to end extreme poverty in our societies. The target is to have not more than 3\% of the world's population subsisting on \$1.25 per day by 2030. To achieve this according to World Bank (2013), will require regular measure of progress made by the different policies used by our different governments. World Bank, (2013) says such actions will assist in guiding and measuring the effectiveness of developmental strategies such as ecotourism in an economic environment.

In Nigeria, as indicated by the National Bureau of Statistics (NBS) (2009) in Oyekale, Adepoju \& Balogun (2012), the national poverty incidence which was formerly 65.6 percent in 1996 declined to 54.4 percent in 2004. Despite this change according to the literature the number of people below the poverty line was on the increase with more than 70 percent living below $\$ 1$ a day. In 2006, the human development index (HDI) for Nigeria was put at 0.448 , ranking Nigeria $159^{\text {th }}$ among 177 poor nations; indicating Nigeria to be among the poorest of nations (United Nations Development Projects (UNDP), 2006; International Monetary Fund (IMF), 2005). UNDP (2006)'s statistics on the poverty situation in Nigeria says about $70.8 \%$ of the population was below the poverty line in 2003 that this dropped to 60\% in 2006 (Onu \& Abayomi, 2009). In 2010 in absolute 
terms, 61 percent of the Nigerian population was poor (National Bureau of Statistics, 2011).

Oyan Lake (OL) is a man-made natural resource. Aside raw water supply and fisheries development, part of the mandate of OL with its Dam is tourism; tourists make visits to this site for sight-seeing, game viewing, sport fishing and research. Ecotourism at OL is perceived as not generating the supposed revenue for the improvement of the site and economic benefits for the host-communities. The host communities only see tourists around and at times as visitors to their villages, with little or no expected gains from such visits, as they hold little or no tourism - or related business. In terms of fishing, businesses on the Lake seem to yield so little; it seems overexploited, as most fish caught were always small-sized fish; while there are agitations that the site be developed for more ecotourism business to increase revenue generation.

Tourism could contribute meaningfully to the economic development of Nigeria if properly harnessed (Da'silva, 1985; Atewologun, 1986; Dalat, 2010). The local benefits of tourism include poverty elimination, most especially in economies where tourism has very good linkage with the local people or inhabitants (Okech \& Mwagona, 2007), the development of infrastructures, bridging cultural differences. Thus, the local host communities would have access to jobs and wealth creation through the many ecotourism enterprises. Through this, host communities' members would be able to get employed or create own-businesses for sustainability.

Tourism-related enterprises that indigenes could partake include: provision of food and drinks, supplies to hotels (farm and non-farm products), local transport, attractions such as local dancers and entertainments, tourists guiding, production and sales of handicrafts and souvenirs. These provide opportunities for the poor for improved livelihood; tourists are able to visit the destination with the purpose of relaxation and patronizing available goods and services especially fish and fish products as well as agricultural produce. The resulting income and employment generated can help to reduce poverty levels particularly income poverty of the local residents including the poor.

The poor can reduce their poverty if earnings from tourism are used to support health and education services for their families which are linked to poverty alleviation by improving their well-being and capabilities (Moyib, 2017). Remote areas attract tourists because of their origin, cultural, wildlife and landscape values. Infrastructure and social service facilities are established or improved using earnings from tourism. Using such facilities, the poor also not only improve their incomes but also their social wellbeing and capabilities. 
As observed, the host communities of Oyan Lake's environment seem not attractive enough, with inadequate and tattered housing facilities, and dry water-points. These communities are not on the national grid and would not attract tourists for home stays, food and drinks. Thus, a poverty profile of the Lake's host communities becomes important to attract the attention of policy makers to developing pro-poor tourism policies and support-programmes that would help in achieving the goal of eliminating extreme poverty among these communities as well as make them attractive for tourists' visits.

The focus of this study therefore, was the analysis of the poverty status of OL host communities' households - an unpopular tourist attraction in Ogun State, Nigeria. The objectives of the study are: to assess the socioeconomic characteristics of the selected households; to determine household heads' livelihood activities; to assess the poverty status of the households and its determinants.

\section{Poverty Concept and Its Sting on Nigeria}

Poverty is a very complex social problem with many variants and different roots, all of which have validity depending on the situation (Rosegrant, 2006). Perceptions of poverty also vary from culture to culture and from country to country; while as countries become wealthier, their perceptions of acceptable deprivations also change. Poverty according to Olubanjo et al. (2010) can be described as that level of deprivation that encompasses shortfalls or inadequacies in basic human needs, which prevent people from achieving internationally acceptable levels of well-being. Ali, Saboor, Sarfraz \& Mustafa (2010) and Banerjee (2004) opine that the poor are not simply those who are below the prescribed threshold of income and consumption but also confronting a more constrained and difficult environment.

Walter, Harold and Christopher (2004) say the poor have low incomes and lower levels of consumption than those who are not living in poverty. They are characterized by their lack of purchasing power in the market and by human underdevelopment, they are generally socially excluded and have minimal access to education, health and other forms of social welfare enjoyed by others in their society who are not poor; they suffer relative deprivation and are generally marginalized in the decision making processes. They lack access to savings and capital and generally experience high levels of vulnerability to changes in market conditions the resultant effect is that their basic needs are not met and they do not have a state of well-being. Their condition is sometimes referred to as "ill-being" (Walter et al., 2004:3).

Poverty today has many faces; it is more than having low income; it is multidimensional and complex; it relates to issues such as disease, illiteracy, infant mortality, 
environmental degradation and many others. It reflects poor health and education, deprivation in knowledge and communication, inability to exercise human and political rights and the absence of dignity, confidence and self-respect (UNDP, 1997). The poor are clustered in certain socio-economic categories that include small scale farmers, pastoralists, agricultural labourers, casual labourers, unskilled and semi-skilled workers, female-headed households, the physically handicapped, HIV/AIDS orphans and street children. Arguello \& Valdernama-Gonzalez (2015) in their study of sectoral and poverty impacts of agricultural policy adjustments in Colombia made use of the FGT index. Findings from the study indicated that national poverty in Colombia was $42.3 \%$ while extreme poverty was $15.7 \%$. The authors then concluded that poverty and extreme poverty are highest in the rural areas whether at individual or household level; and that more efforts are required to bring those in the rural areas out of poverty.

Absolute poverty is defined in terms of the minimal requirements necessary to afford minimal standards of food, clothing, healthcare and shelter. Using this approach, 54.7\% of Nigerians were living in poverty in 2004 but this increased to 60.9\% (or 99,284,512 Nigerians) in 2010. Of the geo-political zones, the North-West and North-East geopolitical zones recorded the highest rates of poverty at $70 \%$ and $69 \%$ respectively, while the South-West geopolitical zone had the least rate of poverty at $49.8 \%$. At the State level, Sokoto State had the highest at $81.2 \%$ while Niger State had the least at $33.8 \%$. Issues on poverty have also been variedly researched by various scholars on Nigeria and for example, Akinbile \& Ndaghu (2007), Onu \& Abayomi (2009), Awotide, Adetunji \& Agbola, (2010) and Oyekale et al. (2012).

Akinbile and Ndaghu (2007) in their analysis of poverty level and poverty alleviating strategies of farm families in Michika Local Government Area of Adamawa State, Nigeria, used the total income of all members of the household divided by the family size. This was then compared by the authors with United Nations 1998 multinational comparison figure of US $\$ 1$ per day or US $\$ 370$ per year. The result indicated that 93 percent of the farm-families lived below the poverty line, while factors that predicted their poverty level included family size, access to inputs, access to credit and education. Onu \& Abayomi (2009), studied poverty among households in the Yola metropolis of Adamawa state, Nigeria. Findings revealed that $47.5 \%$ of the respondents were below the poverty line while the $\rho_{1}$ and $\rho_{2}$ with values of 0.20 and 0.1 respectively, revealed that the issue of poverty in the study area demands attention. Furthermore, the incidence of poverty was high $(100 \%)$ among the illiterate household heads while poverty incidence, depth and severity were very high among older farmers of age 60 years and above. The study concluded that there is high poverty incidence in the study area.

Oyekale et al. (2012) analysed the poverty status of rural households in Ogun Waterside Local Government Area of Ogun State, using FGT weighted index. Results show that 28.8 
percent of the households were poor, while 0.8 percent was core poor. The poverty depth is 0.0527 while probit results revealed that having farming as primary occupation and household size significantly increased poverty $(\rho<0.10)$, while amount of credit/loan obtained, educational attainments and monthly expenditure of household significantly reduced it $(\rho<0.10)$. Awotide et al. (2010) also related poverty status to livelihood diversification in Southwest Nigeria, using FGT index. The study revealed that the incidence of poverty revealed that the proportion of the farming households whose per capita expenditures fell below the poverty line was 47 percent while severity of poverty in the study area was 8 percent.

\section{Methodology}

\section{The study Area and Sampling Procedure}

Oyan Lake is located on latitude $7^{\circ} 15^{\prime} \mathrm{N}$ and longitude $3^{\circ} 16^{\prime} \mathrm{E}$ at an at elevation of $43.3 \mathrm{~m}$ above sea level on the confluence of Oyan and Ofiki Rivers, both tributaries of Ogun River, and about $20 \mathrm{~km}$ North West of Abeokuta (Ikenweirwe, 2005; OORBDA, 1998). A 270 million cubic meters dam is located on the Lake. It is used primarily to supply raw water to Lagos and Ogun States, and it has potential for use in irrigation and 9 megawatts electricity generation.

The host communities of the Lake's land area fall under Abeokuta North and Odeda Local government areas (LGAs) of the Ogun State. The 2006 estimated population for the two LGAs is 198,793 and 109,522 respectively (NPC, 2006); while the estimated population growth for these areas for year 2015 was put at 267,000 and 147,100 respectively (NPC estimate, 2016). More than 90 percent of these LGAs are rural, while more than $75 \%$ of the people live in the urban areas of the local government areas; non-indigenous residents occupy the rural areas including the Oyan Lake host communities. The urban communities are about 10 kilometres and above away from the Lake, while those that were submerged in the Lake and whose residents were later relocated by the Ogun Oshun River Basin Development Authority (OORBDA) within 2 to 5 kilometres radii are referred to here as the local host community. The local host communities are the displaced communities of Ibaro and Abule-Titun as well as Abule-Sikiru - the only non-displaced community. Ibaro community consists of 11 villages, while Abule-Titun consists of 13 villages. The rainforest expanse of land area around the Lake also houses FulaniHausa men and women in family units called 'Gaa' rearing livestock; while their women produce and sell local cheese.

The study made use of primary data from 367 households (40\% of the population), that were randomly selected proportionate to the size of each village as indicated in Fig. 1. Structured questionnaire and interview method were used to collect data from the 
host communities' households. Variables assessed were socio-economic characteristics of the households, livelihood activities for example fishing, farming, artisanship and households' food and non-food consumption expenditures. The Foster Greer Thorbecke (FGT) index was used to measure the incidence, depth and severity of poverty among households. Multivariate probit model was used to determine the relationships between socio-economic characteristics of the households and their poverty status.

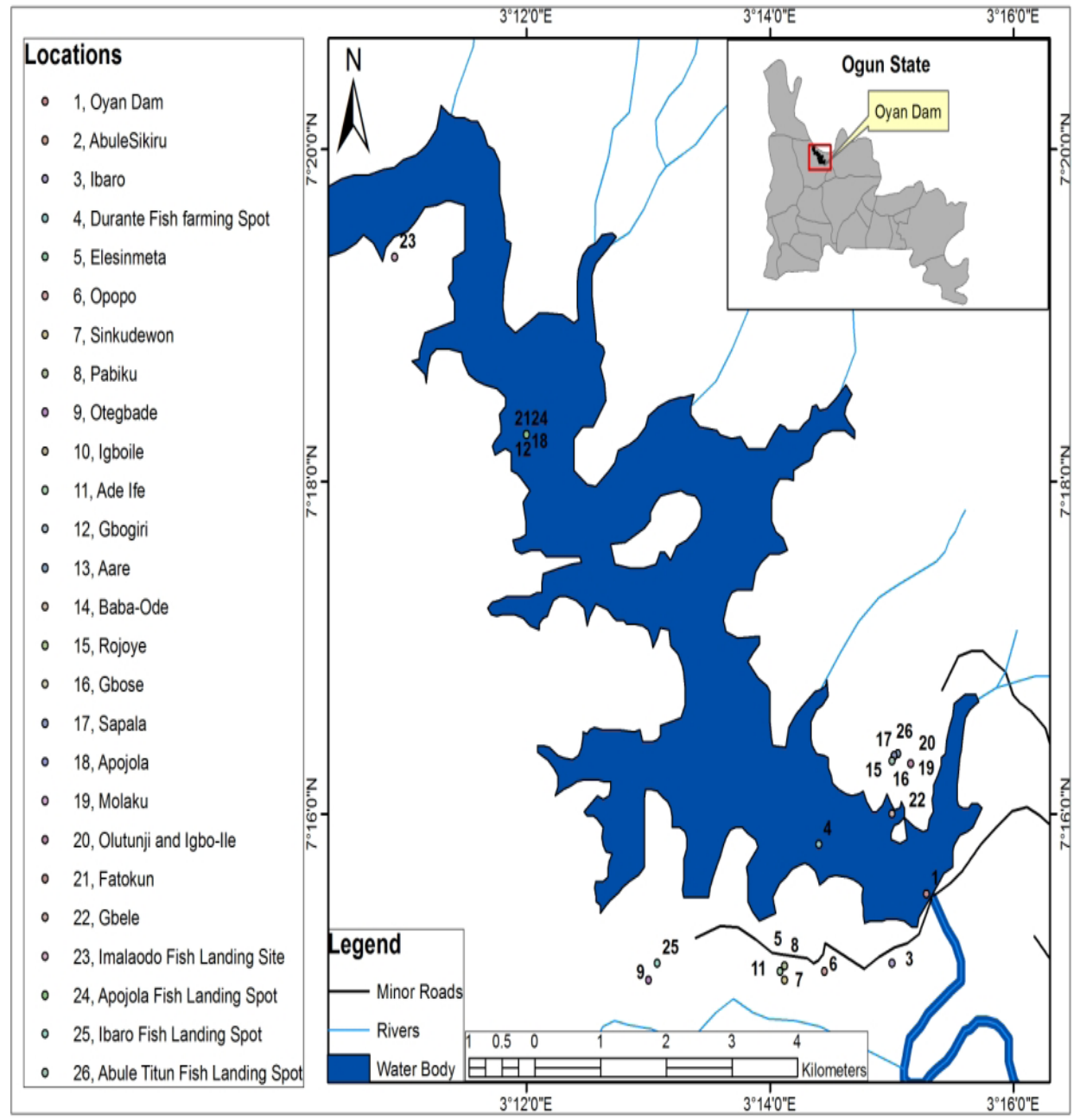

Fig 1: Locations of the host communities on Oyan Lake and the fish landing spots

Source: Department of Geography, Tai Solarin University of Education, Ijagun (2015) 


\section{Estimation of Poverty Line}

The poverty measure used in this study was the headcount index of international poverty line of US\$1.25 per day (N248.75 at \$1= N199.00 in 2015), (see Anyawu, 2013). This was used to determine the percentage of the households that fell below the international poverty line \$1.25/day as declared by the World Bank in 2005. All households below the \$1.25/day equivalent were thus classified as poor while those above were nonpoor. Therefore, the approach used in this study classified the respondents into poor and non-poor based on their level of expenditure on food and non-food per month in relation to the international poverty line of $\$ 1.25 /$ day (N248.75 at $\$ 1=\mathrm{N} 199.00)$ as at the time of the study. To present the poverty profile of the communities, indices such as incidence, depth and severity were computed. The Foster Greer Thorbecke (FGT, 1984) weighted index was used for the quantitative poverty assessment among the household heads in the study area. The FGT poverty measure, which is decomposable by groups and sensitive to the depth of poverty within the poor, were used to assess the above indices among the rural households in the study area. The FGT index allows for the quantitative measurement of poverty status among subgroups of a population and has been widely used (See Oyekale et al. 2012) due to its decomposability among subgroups. The headcount ratio measures the ratio of the number of poor individuals. The poverty gap estimates the intensity of poverty based on the extent of income shortfalls below the poverty line. The analysis of poverty status using FGT measure usually starts with ranking of expenditures in ascending order. The expenditures were ranked such that:

$Y_{l i} \leq Y_{2 i} \leq$ $\leq Y_{q i} \leq Z \leq Y_{(q+1) i} \leq Y_{(q+2) i} \leq$ $\leq Y_{n i}$

The Foster, Greer and Thorbecke (FGT) measure for the ith subgroup $\left(P_{a i}\right)$ is given mathematically as follows:

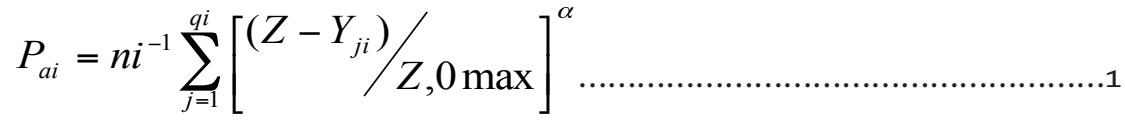

Otherwise written as

$$
P_{\alpha}=\frac{1}{n} \sum_{i-1}^{q}\left(\frac{z-y_{i}}{z}\right)^{\alpha}
$$

Where $\left(P_{\mathrm{ai}}\right)$ is the weighted poverty index for the ith sub-group, $n_{\mathrm{i}}$ is the total number of households in subgroup $i$, $q i$ is the number of the ith subgroup households in poverty,

$Y_{\mathrm{ji}}$ is the per capital expenditure of $i$ th household on food and non-food items $j$ in subgroup $i$; $Z_{i}$ is the poverty-line for the ith sub-group and $\alpha$ is the degree of concern for the 
depth of poverty. The poverty line for the study was thus defined based on international poverty line of $\$ 1.25$; where: $n_{\mathrm{i}}$ is the total number of sampled households, $q_{\mathrm{i}}$ is the number of households below the poverty line. The parameter $\alpha$ reflects poverty aversion, if it is zero, the answer shows head count ratio while 1 value means poverty gap and setting $\alpha$ at 2 amounts to the measure of squared poverty gap.

\section{Determinants of Poverty among the Household-heads in the Host Communities in the study area using the Probit Regression Model}

In order to analyse the determinants of the poverty status of the household heads in the host communities of Oyan Lake, the Probit regression technique was used. The Probit model is a normal cumulative distribution function; the model is estimated using Maximum Likelihood Estimates (MLE) approach, it helps in overcoming the difficulties arising from the non-normality and heteroskedastic variance of the error terms, if Ordinary Least Square Regression Analysis were to be carried out. Such models are referred to as qualitative or binary choice models (Capps \& Krammer, 1985 in Oyekale et al. 2012). The model following Oyekale et al. (2012) is implicitly defined as:

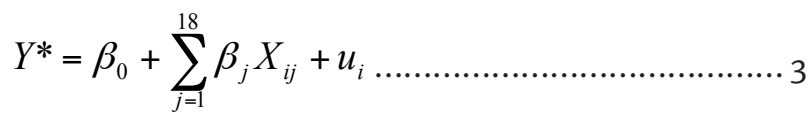

Where $y^{*}$ is not observed. What id is observed is a dummy variable $y_{i}$ defined by

$y_{i}=\left\{\begin{array}{l}1 \\ 0\end{array}\right.$ if $y_{i}>0$; otherwise

$\operatorname{Max} L=\prod_{y_{i}=1} p_{i} \prod_{y=0}\left(1-P_{i}\right)$

$=F\left(Z_{i}\right)=\int_{-\infty}^{z_{-\infty}^{\frac{i}{\sigma}}} \frac{1}{\sqrt{2 \pi}} \exp \left(-\frac{t^{2}}{2}\right) d t$

Where $Y$ is the poverty status dummy (Poor $=1,0=$ Non-Poor),

$j=1 . . . . .18$; with the independent variables as specified below: $X_{1}=$ Sex of Household head ( male = 1 , Otherwise = o); $X_{2}=$ Age (years); $X_{3}=$ Marital Status (Married =1, otherwise o); $\mathrm{X}_{4}=$ Years of Education of the Household head (years); $\mathrm{X}_{5}=$ Household type (Polygamous $=1$, Otherwise = 0); $X_{6}=$ Household size of the Household head; $X_{7}=$ Dependency Ratio; $X_{8}$ $=$ Capital Base (i.e. savings); $X_{9}=$ Years of Residence; $X_{10}=$ Fishing Occupation - Occufish (Fishing = 1, $0=$ Otherwise); $X_{11}=$ Primary Occupation (Farming = 1, Otherwise $=0$ ); $\mathrm{X}_{12}=$ Type of Housing Unit (Flat = 1, Otherwise = O); $\mathrm{X}_{13}=$ Type of Toilet (Flush-toilet = 1 , Otherwise $=0$ ); $\mathrm{X}_{14}=$ Distance to Clinic (kilometres); $\mathrm{X}_{15}$ Source of Drinking water (Tap water $=1$, otherwise $=0$ ); $X_{16}=$ Source of electricity for Light (Generator $=1$, Otherwise $=0$ ); $X_{17}=$ Source of energy for cooking $\left(\right.$ Gas/Kerosene $=1$, otherwise $=0$ ); $X_{18}$ Road 
Infrastructure (Presence of rural road network $=1$, otherwise $=0$ ); $\ell_{i}=$ Stochastic error term.

\section{Results and Discussion}

\section{Socio-demographic Features of the Selected Household heads in the Host Communities}

The results indicated that only 28.6 percent of the respondents were females while the remaining were males. The mean age of the respondents was 44 years; most of the respondents were in the age range of 21 to 60 years (87.47 percent). The mean household size was 4 members. Most respondents had household size ranging from 1 to 4 members (61.6\%) while the remaining $38.4 \%$ had household size of $5-8$ members. On education, majority (52.60 \%) of the selected household heads were not educated; however, those with primary education account for 27.60 percent while those with secondary and tertiary education formed $\mathbf{1 9 . 0 \%}$ and $0.80 \%$ respectively. The income range of the household heads was N120,000 to N600,000 per annum; those with less than N150,000 per annum account for 6.80 percent of the selected population with many of the residents' income falling between N151,000 to N300,00o per annum.

The analysis of the livelihood activities of the host communities around Oyan Lake indicated that $39.8 \%$ of the host community members were engaged in farming activities, while 24.8 percent engaged in artisanal fishing activities on the Lake, which indicates that only this percentage tap this water resource for its free gift of fish for livelihood. Other activities noted among them were trading, construction works, crafts and artisanship and employment in the formal which constituted 10.1, 7.4, 8.5 and 4.10\% respectively. Mining of sands and stone is carried out in these communities but by nonresident transporters who pay entrance/loading fees at OORBDA gates. Such miners are seen making entry/exit with their labour hands, without engaging the community members. 
Table 1: Livelihood activities of the host communities

\begin{tabular}{|l|l|l|}
\hline Activities & Frequency & \%ages \\
\hline Farming & 146 & 39.80 \\
\hline Artisanal Fishing & 91 & 24.80 \\
\hline Trading & 37 & 10.10 \\
\hline Formal Sector - Employment & 15 & 4.10 \\
\hline Crafts and Artisanship & 31 & 8.50 \\
\hline Construction works & 27 & 7.40 \\
\hline Fish processing and Others & 20 & 5.30 \\
\hline Total & 367 & $\mathbf{1 0 0}$ \\
\hline
\end{tabular}

Source: Data Analysis (2015)

The mean total household expenditure on food, clothing, house rent, children's tuition fees and health per month in the study area was N17,422: oo; while the range was between N7,500 and N33,00o per household per month (See Table 2). As indicated in Table 3, 40.9\% of the selected household heads expended less than N15,001:00 per month on their basic needs; while 18.8 percent spent more than N20,00o on household basic needs per month.

Table 2: Descriptive statistics of households and expenditure on Basic needs per Month in the Study Area

\begin{tabular}{|l|l|l|l|l|}
\hline Variables & Min. & Max. & Mean & Std. Dev \\
\hline Age of House-head (HH)(years) & 19 & 85 & 44 & 13.5 \\
\hline Education level of HH(years) & 0 & 15 & 3.9 & 4.6 \\
\hline Household size (no) & 1 & 8 & 4 & 1.6 \\
\hline Food expenditure (N) & 6,000 & 25,500 & 11,794 & 3,820 \\
\hline Clothing and Housing Exp. (N) & 500 & 5,500 & 1,264 & 1,246 \\
\hline Tuition fees and Health Exp. (N) & 0 & 6,500 & 2,308 & 1,760 \\
\hline Total HH Expenditure (N) & $\mathbf{7 , 5 0 0}$ & $\mathbf{3 3 , 0 0 0}$ & $\mathbf{1 7 , 4 2 1}$ & $\mathbf{5 , 5 4 2}$ \\
\hline
\end{tabular}

$\mathrm{N}=$ Naira; $1 \$$ Equivalent to $\mathrm{N} 199$ at the time of the study

Source: Data Analysis, 2015 
Table 3: Range of total household expenditure on some basic needs per Month in the Study Areas

\begin{tabular}{|l|l|l|l|}
\hline Total Expenditure (N) & Freq. & \% & Cumm. \% \\
\hline $\mathbf{7 , 5 0 0 - 1 0 , 0 0 0}$ & 17 & 4.6 & 4.6 \\
\hline $\mathbf{1 0 , 0 0 1 - 1 2 , 5 0 0}$ & 57 & 15.6 & 20.2 \\
\hline $\mathbf{1 2 , 5 0 1 - 1 5 , 0 0 0}$ & 76 & 20.7 & 40.9 \\
\hline $\mathbf{1 5 , 0 0 1 - 1 7 , 5 0 0}$ & 66 & 18.0 & 58.9 \\
\hline $\mathbf{1 7 , 5 0 1 - 2 0 , 0 0 0}$ & 49 & 13.3 & 72.2 \\
\hline $\mathbf{2 0 , 0 0 1 - 2 2 , 5 0 0}$ & 33 & 9.0 & 81.2 \\
\hline $\mathbf{2 2 , 5 0 1 - 2 5 , 0 0 0}$ & 33 & 9.0 & 90.2 \\
\hline $\mathbf{2 5 , 0 0 0}$ & 36 & 9.8 & 100 \\
\hline Total & 367 & $\mathbf{1 0 0}$ & - \\
\hline
\end{tabular}

Source: Data Analysis, 2015

\section{Poverty Analysis of the Host Communities Based on Households Expenditure on Basic Needs}

The monthly households' total expenditure on food and non-food items such as expenses on clothing, children schooling, house rent were estimated, and from this the mean household monthly per capital consumption expenditure on food and non-food items was calculated. The poverty statuses of the selected households were analysed by decomposing it into three indicators as follows: incidence of poverty or head count poverty status $\left(\mathrm{P}_{\mathrm{o}}\right)$, poverty gap or depth $\left(\mathrm{P}_{1}\right)$ and poverty severity $\left(\mathrm{P}_{2}\right)$. The incidence of poverty $\left(\mathrm{P}_{\mathrm{o}}\right)$ indicates the percentage of the households falling below the poverty line, poverty gap or depth $\left(\mathrm{P}_{1}\right)$ shows the amount by which the poor fall short of the poverty line while poverty severity $\left(\mathrm{P}_{2}\right)$ is the sum of square of poverty gap or poverty depth divided by the number of poor households in the host-communities. Poverty severity gives more magnitude (i.e. value) to the poorest households. That is the closer the value of poverty severity is to 1 , the more severe is poverty among the selected households.

Based on the FGT, the poverty incidence (headcount index - H) among the households was 0.817 , the depth of poverty (otherwise called the poverty gap index) was with a value of 0.45 while the squared poverty gap index (severity) was 0.24 (See Tables 4 and 5). The result indicated that 81.7 percent of the host communities were poor while 18.3 percent were non-poor. The poverty depth among the poor household was 0.45 , which indicated that an average poor household in the host communities of Oyan Lake would require $45 \%$ of the poverty line (i.e. $0.45 \times \mathrm{N} 7,426.5=\mathrm{N} 3,341.92$ ) to get lifted out of poverty. The mean poverty severity index for these poor household was given as 0.236 which depicts the severity of poverty in the study area. It measures the extent of poverty in the study area. The closer to 1 the value is, the higher the degree of severity, while the farther away from 
1 it is the lesser the degree of poverty severity. Following Oyekale et al. (2012), this means that the severity of poverty among the poor household was 23.6 percent. This indicated that of the poor households, the core (severely) poor households were just about $23.6 \%$ of the poor and $19.35 \%$ of the whole population, while the moderately poor accounted for $76.4 \%$ of the poor (See Table 5) and $62.39 \%$ of the selected population. From Table 6, it could be observed that only $18.26 \%$ (approximately 18.3\%) of the selected community households were non-poor, $62.39 \%$ moderately poor while $19.35 \%$ were core poor.

Table 4: Poverty measures for Oyan Lake host communities' households $(\mathrm{n}=367)$

\begin{tabular}{|l|l|}
\hline Poverty measure & Value \\
\hline Head Count & 0.817 \\
\hline Poverty Gap & 0.454 \\
\hline Squared poverty index & 0.236 \\
\hline Poverty line per week & $\mathrm{N} 1,865.625$ \\
\hline Poverty line per month & $\mathrm{N} 7,462.5$ \\
\hline Poverty line per year & $\mathrm{N} 89,550$ \\
\hline
\end{tabular}

Source: Data Analysis (2015) (\$1 = N199 as at March, 2015)

Table 5: Incidence of poverty among host communities in Oyan Lake

\begin{tabular}{|l|l|l|}
\hline Status & Frequency & Percentage \\
\hline Non-Poor & 67 & 18.3 \\
\hline Poor & 300 & 81.7 \\
\hline Total & 367 & 100 \\
\hline
\end{tabular}

Source: Data Analysis (2015)

Table 6: Classification of the households by poverty level

\begin{tabular}{|l|l|l|}
\hline Variable & Frequency & \%age \\
\hline Non-Poor & 67 & 18.26 \\
\hline Moderately Poor & 229 & 62.39 \\
\hline Core Poor & 71 & 19.35 \\
\hline Total & $\mathbf{3 6 7}$ & $\mathbf{1 0 0}$ \\
\hline
\end{tabular}

Source: Data Analysis (2015) 


\section{The Depth and Severity of Poverty among the Poor Households among Oyan Lake Host Communities}

The poverty gap index $\left(\mathrm{P}_{1}\right)$ and severity of poverty $\left(\mathrm{P}_{2}\right)$ among the households were estimated, $\mathrm{P}_{1}$ index indicated the amount of fund required to lift the poor to the poverty line while the $\mathrm{P}_{2}$ indicated the severity of poverty among the poor households of the host community of Oyan Lake. The results of the analysis for these community indicated that the mean poverty gap index as 0.45 (i.e. $45 \%$ ) which means that the poor in this area would require an average of $45 \%$ of the poverty line to move out of poverty ( $0.45 \mathrm{x}$ $\mathrm{N}_{7,462.5}$ N3,358.125. As a large percentage of this community were poor $(81.7 \%$ of them in all), this indicated that the incidence of poverty was very high for people living around the Lake. Statistics show that the minimum poverty gap index was 0.06 (6\%) while the maximum poverty gap index was 0.82 (82\%). This indicated that in assessing each of the poor households, the extreme poor among the households would require ( $0.82 \times \mathrm{N} 7,462.5$ $=\mathrm{N6119.25}$ ) to get to the poverty line; while the least poor would require (0.06 x N7,462.5 $=\mathrm{N} 447.75$ ) to move out of poverty. The mean severity poverty index was indicated as 0.23 which suggested that the severity of poverty among these poor households was low, but based on World Bank's target; the severity was still high, while the degree of severity ranged between 0.04 and 0.66 . This indicated that while some were moderately poor, others were core poor.

Table 7: Over-all depth and severity of absolute poverty among Oyan Lake host communities $\left(n=300^{*}\right)$

\begin{tabular}{|l|l|l|}
\hline Variable $\left(\mathbf{P}_{\mathrm{o}}\right)$ & \left. Poverty Gap ${\left(\mathbf{P}_{1}\right)}\right)$ & $\operatorname{Sen} \operatorname{Index}\left(\mathbf{P}_{2}\right)$ \\
\hline Mean & 0.454 & 0.236 \\
\hline Standard Dev. & 0.173 & 0.151 \\
\hline Standard Error of Mean & 0.010 & 0.009 \\
\hline Minimum & 0.062 & 0.004 \\
\hline Maximum & 0.815 & 0.665 \\
\hline Range & 0.754 & 0.662 \\
\hline
\end{tabular}

* (i.e. the poor population) Source: Data Analysis (2015).

\section{Determinants of Poverty among Households in the Host Communities of Oyan Lake}

In analysing the factors that contributed to poverty as well as pointers to poor households the multivariate probit model was used. Estimates of the probit model on the interrelationship between the poverty level and socio-economic characteristics of the selected households as indicated by the likelihood ratio (LR) statistic shows that the model was significantly different from zero by 280.85 at 1 percent level attesting to the 
goodness-of - fit of the model. Of the eighteen variables used in the model, only six (6) variables were statistically significant, the variables were marital status; educational status of the household head; household type; household size; capital base i.e. savings and liquid assets, and housing unit. The marital status, household type, house-hold size and housing units showed a positive and significant effect on the poverty status of the household heads in the host communities. The coefficient associated with marital status being positive and significant indicated that being married increases the probability of being poor. This means that to be single or unmarried increases the chance that one will not likely fall into poverty, based on the fact that there will be little or no dependency from family members. The marginal effect of marital status is positive also indicating that being married increases the probability of being poor by 0.9 percent. As most of residents are married, this has increased their chances of being poor, due to dependency level. Also, being married and poor increases the chances of depending more on OL, for family sustenance without taking cognisance of renewable resource loss and degradation that can deepen the community into poverty.

Also, the coefficient of household type was positive and significant at $10 \%$ level. The result connotes that being polygamous household increased the probability of being poor; this is probably due to increasing tendencies of having larger household sizes for the polygamists. The marginal effect after the probit regression was positive at 0.002 . This indicated that families that tend towards polygamy increase their chances of being poor by $0.2 \%$. However, the coefficient associated with household size was positive and significant at $1 \%$. This means that increases in household sizes increase the probability of being poor. The result indicated that household size play a very significant role in being poor, which means that the higher the household size especially those with high dependency ratio, the more the poverty or the farther away the household will be from the poverty line. The result of the marginal effect was positive at 0.002, indicating that an increase in household size by one unit increases the probability of being poor by $0.2 \%$. This result goes along with that on household type, which means that increasing family size either through multiple marriage (marrying more wives) and/or bearing more children increases such families' probability of being poor. This result goes along with the study of Fabiyi et al. (2008), which concluded that increased household size, increases the probability of being poor.

As expected the coefficient associated with type of housing unit, which is an indication of money power in our society, even the location of the housing unit; was positive and significant at $10 \%$, this means that with the house heads' level of monthly income, living in a flat, or single detached housing unit (self-contained apartments with two and above bedroom per family); increases the households' probability of being poorer than households who live in one or two room rented houses. Payments for such housing units 
with people with low economic powers increases their probability of being poorer than expected or poor.

However, education level and capital base of the household heads revealed a negative but significant effect on the poverty status of the respondents and by extension in the study area. This implies that increases in the level of formal education and capital base will decrease the probability of being poor for the household heads, all others remaining constant. As expected the coefficient associated with formal educational level of the household heads was negative and significant effect at $\mathrm{p}<0.1$, this indicates that a reduced level of education increases the probability of being poor. This implies further that increases in formal educational levels of the household heads would decrease the probability of being poor, all things being equal. This indicates that the less educated persons are more vulnerable to poverty than well-educated persons. The logit analysis of the relationship between socio-economic characteristics of small-scale farmers in Ogbomosho and poverty level, also detected that the probability of being poor is reduced by increases in educational level (See Fabiyi et al. 2008).

The marginal effect after the probit regression was also negative at 0.00007; this indicates that being uneducated increases the probability of being poor by 0.007 percent. Therefore, a year increase in the household heads' formal educational level would decrease the probability of their being poor by $0.007 \%$. This goes to indicate that aside formal education, increases in education would help in reducing over exploitations of natural resources in and around OL for sustainable growth. Fisheries resources in the OL can be sustained for growth if host communities' households possess the required conservation education. Findings on the challenges of fisheries resource management practices on River Benue and its tributaries in Mayo Ranewo community shows high level of illiteracy among the fishing folk, resulting in overexploitation of the waters and difficulties in effective enforcement of fishery regulation in the area (See Oruonye, 2014).

Also, the coefficient associated with capital base (savings) of the house-hold heads was negative and significant at $1 \%$, capital base as it were is a form of savings which the household keeps in lieu of present or future business. The result of this variable being negative and significant indicated that as the capital base of the household head increases, the probability of being poor decreases. This indicated that households with little or no capital base have a high probability of being poor. The result of the marginal effect after probit regression analysis indicated a very low chance of $0.00001 \%$ of falling into poverty, if capital base of the household head should increase by one naira. Therefore, increases in capital base increases household heads' ability to increase investments in fishing gadgets and other businesses. 
Table 8: Estimates of the relationship between the poverty level and socio-economic characteristics of the host communities in the study Area

\begin{tabular}{|c|c|c|c|c|c|}
\hline Variable & Coeff. & Std. Err. & $\mathbf{z}$ & $\mathbf{P}>|\mathbf{z}|$ & Mar. effect \\
\hline Sex & -0.566 & 0.429 & -1.32 & 0.187 & $-0.0003^{*}$ \\
\hline Age & -0.017 & 0.021 & -0.78 & 0.438 & -0.000013 \\
\hline Mstat & 1.357 & 0.708 & 1.92 & $0.055^{*}$ & $0.009^{*}$ \\
\hline Edulev & -0.087 & 0.046 & -1.91 & $0.056^{*}$ & -0.00007 \\
\hline Hhtype & 1.982 & 1.059 & 1.87 & $0.061^{*}$ & $0.002^{*}$ \\
\hline Hhsize & 2.113 & 0.451 & 4.68 & $0.000^{* * * *}$ & 0.002 \\
\hline Depratio & -0.950 & 0.591 & -1.61 & 0.108 & -0.0008 \\
\hline Capbas & 0.000014 & $4.05 \mathrm{e}-06$ & $-3 \cdot 33$ & $0.001^{* *}$ & $-1.07 e-08$ \\
\hline Yresid & 0.037 & 0.031 & 1.19 & 0.235 & 0.00003 \\
\hline Occufish & 0.265 & 0.513 & 0.52 & 0.605 & $0.00017^{*}$ \\
\hline Pryoccu & -0.186 & 0.478 & -0.39 & 0.698 & $-0.00016^{*}$ \\
\hline Housunit & 3.179 & 1.736 & 1.83 & $0.067^{*}$ & $0.0005^{*}$ \\
\hline Toiletype & 1.159 & 1.016 & 1.14 & 0.254 & $0.0003^{*}$ \\
\hline Dstclinic & 0.038 & 0.058 & 0.66 & 0.511 & 0.00003 \\
\hline Watersrc & 0.615 & 3.595 & 0.17 & 0.864 & $0.0002^{*}$ \\
\hline Lightsrc & 0.510 & 0.420 & 1.21 & 0.224 & $0.0006^{*}$ \\
\hline Cookfuel & -0.311 & 0.508 & -0.61 & 0.541 & $-0.0002^{*}$ \\
\hline Roadinfra & -0.045 & 0.407 & -0.11 & 0.911 & $-0.00004^{*}$ \\
\hline Constant & -4.887 & 1.784 & -2.74 & 0.006 & \\
\hline Log likehood & $-33 \cdot 992$ & & & & \\
\hline LR Chi ${ }^{2}(18)$ test & 280.85 & & & & \\
\hline Pseudo $\mathbf{R}^{2}$ & 0.81 & & & & \\
\hline$n=367$ & & & & & \\
\hline
\end{tabular}

Marginal effect - $\left(^{*}\right)$ dy/dx is for discrete change of dummy variable from o to 1, Source: Data Analysis, 2015

** Depratio - Dependency ratio; Capbas - Capital base (Savings and Asset); Yresid - Years of residence; Occfish Fishing occupation; Pryoccu - Primary occupation; Housunit - Type of housing unit of respondents; Toiletype

- Toilet type; Dstclinic - Respondents' distance to health clinic; Watersrc - Source of drinking water; LightSrc

- Source of electricity for light; Cookfuel - Source of energy for cooking; Roadinfra - Presence of rural road infrastructure (See page 9).

\section{Conclusion and Recommendation}

Despite various strategies used in combating poverty in Nigeria it still reflects on the faces of many, especially in the rural areas. The study examined standard of living among Oyan Lake host communities using poverty measure. It was detected that $18.3 \%$ of the selected communities' households were non-poor, $76 \%$ moderately poor while 
$5.7 \%$ were core poor. It is concluded that though a large percentage of the households were poor, the severity of poverty among the selected households was low (0.236). This indicated that many of the households were moderately poor with only $19.35 \%$ being severely affected by poverty. The results of the relationship between the socioeconomic characteristics of the respondents and their poverty level indicated marital status, level of formal education of the household heads, household type, household size, capital base, and housing unit as the significant variables that affect poverty among the selected households. It then shows that if government policies are directed towards these variables, most importantly education (including conservation education), these would assist in lifting households in the study area out of poverty. In this wise, policies aimed at discouraging early marriages and polygamy, having improved family planning and health clinics as well as building more educational facilities for these communities should be given priority. Since the poor according to Browkay (2006), derive a higher percentage of their income from natural resources; it becomes imperative that Nigerian government should also consider giving conservation education a priority for OL host communities being poor, for sustainability. Also, to conserve the fishery resources of OL, there is the need to develop alternative sources of income to substitute practices that could negatively impact the Lake among the fisher folks and other members of the host communities. Also, policies that would focus on improved housing schemes and putting finance agencies in place for easy access to loans for these households should be considered for improved standard of living. At all levels, government should include poverty alleviation as a key aim in tourism development as well as consider tourism as a strategic tool for reducing poverty.

\section{References}

Akingbile, L. A. and Ndaghu A. A. T. (2007). Poverty level and poverty alleviating strategies of farm families in Michika L.G.A of Adamawa State, Nigeria. Journal of Economic and Rural Development, 14(2), pp. 101.

Ali I., Saboor A., Sarfraz A. and Mustafa I. (2010). Relative poverty dynamics in Pakistan, Pakistan J. of Science 47(1), pp. 45 - 52. Accessed: 13/5/2014 http://www. pakjas.com.pk.

Anyawu J.C. (2013). Determining the correlates of poverty for inclusive growth in Africa. Working paper series. African Development Bank Group. No 181, September.

Arguello R. and Valdernama-Gonzalez D. (2015). Sectoral and poverty impacts of agricultural policy adjustments in Colombia. Agric. Econs, 46 (2), pp. $266-267$.

Atewologun, O. K. (1986). History of Lagos and the growth of hotel industry today. Hoteliers Association of Nigeria, Lagos. 
Awotide O. D., Adetunji L. K. and Agbola P. O. (2010). Poverty and rural livelihood diversification among farming households in Southwest - Nigeria. J. of Food, Agriculture and Environ. 8 (1), pp. 367-371.

Banerjee, A. (2004). The two poverties. In S. Dercon Insurance against poverty, (ed). Oxford University Press.

Browkay, J. (2006). Issues in poverty and natural resource management. US Agency for International Development.

Capps O. J. and Krammer R. (1985). Analysis of food stamp participation using qualitative choice model. American J. of Agri. Econs, 67, pp. 49 - 59.

Dalat G. (2010). Developing rural based tourism as a strategy for rural development in Nigeria; Int. J. Creativity and Tech. Dev. (2), pp. 1-3.

Da'Silva, M. C. (1985). Public service lecture: Opportunities for Nigeria in the tourism industry. Paper Presented at the Nigerian Institute of International Affairs, Lagos, 2nd April.

Fabiyi, Y. L., Adetunji M. O. and Ayanwola J. T. (2008). The incidence and severity of poverty among Small-scale farmers in Ogbomoso Area of Oyo State, Inter. J. of Agri. Econ and Rural Dev. -1 (2).

Federal Government of Nigeria (FGN) (2006). Poverty profile for Nigeria. National Bureau of Statistics Federal Republic of Nigeria, Abuja.

Foster, J., Greer J. and Thorbecke E. (1984). A Class of Decomposable Poverty Measures. Econometrica, 52 (3), pp. $761-766$.

Ikenweirwe, N.B. (2005). Limnology and plankton abundance in relation to fish production in Oyan Lake, South Western, Nigeria. A PhD. Thesis Submitted to the Department of Aquaculture and Fisheries Management, Federal University of Agriculture, Abeokuta, Ogun State.

Moyib F. R. (2017). Assessment of the ecotourism potentials of Oyan Lake and host communities households' overty status, Ogun State, Nigeria. Unpublished PhD dissertation submitted to the Department of Wildlife and Ecotourism Management, Faculty of Agriculture and Forestry, University of Ibadan, Nigeria.

International Monetary Fund (2005). Global report for 2005.

National Bureau of Statistics. (2009). Nigeria: 2009 annual abstract of statistics. Federal Republic of Nigeria, Abuja.

Nigerian Bureau of Statistics (2011). Nigeria: 2011 annual abstract of statistics. Federal Republic of Nigeria, Abuja. 
National Population Census (2006). National Bureau of Statistics Official Gazatte (FGP 71/52007/2,500(OL24), Abuja. http://www.nigerianstat.gov.ng. Accessed 13/5/14.

National Population Census (2016). Projected Population estimates for 2015. Retrieved from: http://www.niigerianstat.gov.ng Ogun Oshun River Basin Development Authority (1998). Annual report for the year.

Okech R. N. and Mwagona M. (2007). Tourism contribution in local economies: Focus on poverty Reduction in Kenya. A paper in the Department of ECOHIM, Faculty of Science, Masena University, Maseno, Kenya. pp 6. Retrieved from www.iipt.or/ africa2007/PDFs/Roselyn.pdf.

Olubanjo 0.0., Akinleye S.o. and Soremekun W.A. (2007). Poverty determinants among farmers in Ogun State, Nigeria. Agricultural Journal, 2 (2), pp. 275 - 80.

Onu J. I. and Abayomi z. (2009). An analysis of poverty among households in Yola Metropolis of Adamawa State, Nigeria. J. of Social. Sc., Kamla-Raj. 20 (1), pp. 43-48.

Oruonye E.D. (2014). The Challenges of fishery resource management practices in Mayo Ranewo Community in Ardo Kola local government area, Taraba State Nigeria, Global Journal of Science Frontier Research, Agriculture and Veterinary 14 (3), pp. 1 - 13.

Oyekale A. S., Adepoju A. O. and Balogun A. M. (2012). Determinants of poverty among riverine rural Households in Ogun State, Nigeria. Stud. Tribes Tribals, 10 (2), pp. $99-105$.

Rosegrant, M.W., Ringler, C., Benson, T., Diao, X., Resnick, D., Thurlow, J., Torero, M. and Orden, D. (2006). Agriculture and achieving the Millennium Development Goals. World Bank, Washington, DC, USA.

United Nations Development Programme (1997). Human Development Report. UNDP: New York, USA.

United Nations Development Programme (2006). Human Development Report, Annual Report, Abuja.

Walter J., Harold G. and Christopher E. (2004). Contribution of tourism to poverty alleviation pro-poor tourism and the challenge of measuring impacts for transport policy and tourism section, Transport and Tourism Division, UNESCAP, pp. $1-38$.

World Bank (2013). The World Bank Group Goals: End extreme poverty and promote shared prosperity. Washington, D.C. World Bank. 